\title{
The Effect of Service Quality, Product Quality and Customer Satisfaction on Customer Loyalty of Bank Nagari Main Branch Padang
}

\author{
Elidawati ${ }^{1}$, Yasri ${ }^{2}$, Idris $^{3}$ \\ ${ }^{1}$ Dept. of Management, Faculty of Economics, Universitas Negeri Padang, Padang, Indonesia \\ $\triangle$ (e-mail) elidawathy.unp@gmail.com \\ ${ }^{2}$ Dept. of Management, Faculty of Economics, Universitas Negeri Padang, Padang, Indonesia \\ $\triangle$ (e-mail) yasri.feunp@gmail.com \\ ${ }^{31}$ Dept. of Management, Faculty of Economics, Universitas Negeri Padang, Padang, Indonesia \\ $\triangle$ (e-mail) idris_unp@yahoo.co.id
}

\begin{abstract}
The purpose of this study is to analyze the influence of service quality, product quality and customer satisfaction on customer loyalty in Bank Nagari main branch of Padang. This study used 300 respondents as the sample. The data analysis technique used in this study was path analysis. The results of the research show that service quality and product quality influence customer satisfaction of Bank Nagari branch Padang. Service quality, product quality, and customer satisfaction have significant effect on customer loyalty in Bank Nagari branch Padang.
\end{abstract}

Keywords: service quality, product quality, satisfaction, and loyalty

\section{Introduction}

In the face of the era of economic competition in the world today required a loyal consumer to keep the company still exist. including companies engaged in the field of leveraging the needs of loyal customers. The growth of banking business is growing in Indonesia. This is marked by the establishment of many private banks, both local and foreign investment. All that cannot be separated from the success of development and economic growth is quite rapid. Each bank seeks to raise funds from the community in the form of deposits and redistribute the funds in the form of loans. Various attempts were made by banks to maintain their existence.

Loyalty can mean a person's loyalty to a product either goods or services particular. Customer loyalty is a manifestation and continuation of customer satisfaction in using the facilities or services provided by the bank, and to remain a customer of the bank. Customer loyalty is an absolute thing for a bank that wants to exist in its business, because finding new customers is difficult but much more difficult to retain old customers. Banks that want to win the competition are not measured by the number of customers who open accounts in the short term but must be sustainable in a long time so that customers stay in contact with the bank.

The phenomenon that occurred in Bank Nagari main branch Padang indicates the low customers' loyalty towards Bank Nagari branch Padang. Griffin $(2009,16)$ states that loyalty refers more to the behavior of corporate decision-making units to use or conduct repeated transactions to a product and there is intention to always use these products in the future, customers are said to be loyal if they have a strong commitment to use or conduct repeated transactions on a product and there is an intention to always use the product in the future. If customer loyalty is low then please know the factors that affect customer loyalty of Bank Nagari main branch Padang. Factors that are likely to affect customer loyalty at Bank Nagari main branch Padang is the quality of service, product quality and customer satisfaction.

Shi et al. (2014), found that service quality had an immediate effect on loyalty. According to Giovanis (2008), found that the quality of service indirectly affects customer loyalty, through customer satisfaction and corporate image. Whereas, Kranias at al. (2013) found indirect link between quality and customer loyalty. In particular, the findings highlight the effect of satisfaction mediation 
on the relationship between quality and loyalty. Consumer perceptions of service quality are important variables that determine the same level of satisfaction, and customer satisfaction plays a mediating role in service quality that drives customer loyalty. In winning business competition, it is important to pay attention to the quality of service provided to customers, in order to achieve customer satisfaction in the end can create customer loyalty.

Customer satisfaction in order to create then what is perceived by the customer about the quality of the product must be greater than expected so as to create satisfaction which in turn they will be loyal to the product. Murtiyanto (2014) found that product quality gives positive and significant influence to consumer loyalty through consumer satisfaction. This shows that high product quality tends to create high consumer loyalty also through the satisfaction of every consumer and vice versa. Utami (2015, found the relationship between product quality and loyalty through customer satisfaction. By improving the ability of a product will create a competitive advantage so that customers become more loyal. Customer satisfaction is highly dependent on how the quality of products offered. Consumers will be loyal if the products obtained or purchased by consumers in accordance with the expected so that the consumer's satisfaction created a consumer that makes it difficult to switch to other products and still use the product.

Based on the phenomenon that occurred in Bank Nagari Padang main branch and refers to previous research, this study aims to examine the influence of service quality, product quality and customer satisfaction on customer loyalty of Bank Nagari main branch Padang.

The research hypotheses are:

$\mathrm{H}_{1}$ service quality has a significant effect on customer satisfaction of Bank Nagari branch Padang $\mathrm{H}_{2}$ product quality has a significant effect on customer satisfaction of Bank Nagari branch Padang $\mathrm{H}_{3}$ service quality significantly affects customer loyalty of Bank Nagari branch Padang $\mathrm{H}_{4}$ product quality significantly influences customer loyalty of Bank Nagari branch Padang $\mathrm{H}_{5}$ customer satisfaction has a significant effect on customer loyalty of Bank Nagari branch Padang

\section{Methods}

Based on the formulation of the problem and the purpose of research, this study is a causative research. The population of this research is all customers of Bank Nagari branch Padang. The data collection was conducted by distributing questionnaires to respondents. This research used survey technique with 300 respondents. The method of analysis used in this study was path of analysis of the effects of exogenous variables and endogenous variables.

\section{Results and Discussion}

Path analysts are used to see the effect of exogenous variables on endogenous variables through other endogens (intervening variables) and measure the direct and indirect effects of one variable on other variables. The following is the result of the first substructure of analysis in this study:

Table 1 Results of first substructure analysis

\begin{tabular}{lcccc}
\hline \multicolumn{1}{c}{ Variable } & Coefficient & t-value & Sig. & Result \\
\hline Service Quality $\left(\mathrm{X}_{1}\right)$ & 0.351 & 3.534 & 0.001 & Significant \\
\hline Product Quality $\left(\mathrm{X}_{2}\right)$ & 0.271 & 2.726 & 0.008 & Significant \\
\hline R Square $=0.294$ & & & & \\
\hline \multicolumn{1}{c}{ Source: Primary Data (2017) } & & & &
\end{tabular}

From the above calculation results, the coefficient of each independent variable along with $t$ test results as follows:

a. The coefficient of Service Quality is 0.351 and t-value is 3,534 on sig. 0,001 which is smaller than alpha 0,05 . this result shows there is effect of service quality to satisfaction.

b. The coefficient of Product Quality is 0,271 and t-value is 2,728 on sig. 0,008 which is smaller than alpha 0,05 . this result shows there is effect of product quality to satisfaction 
The calculations show that there is an influence of service quality on satisfaction, the influence of product quality on satisfaction. Based on the above calculation, it can be shown the analysis diagram as follows:

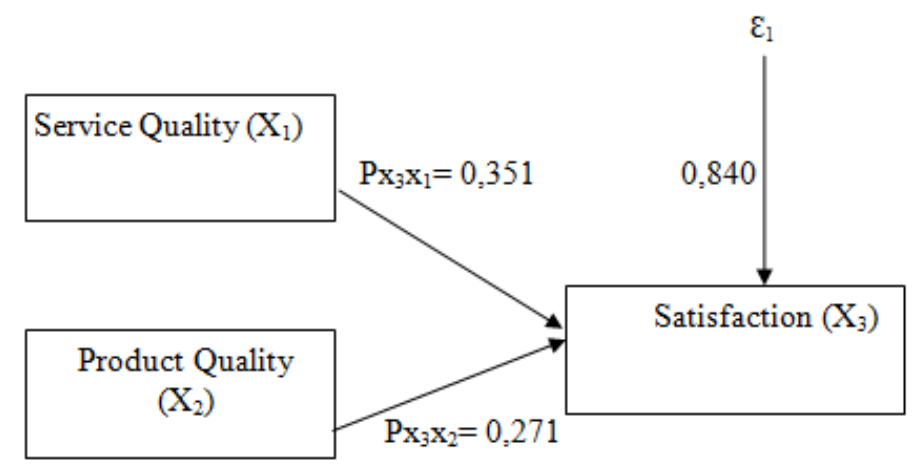

Figure 1 First sub-structure of path analysis

Based on the results of data analysis, that the quality of service, product quality influence on customer satisfaction. Therefore, data analysis can be continued to the second sub-structure

The results of the second structure analysis show the effect of service quality $\left(\mathrm{X}_{1}\right)$, product quality $\left(\mathrm{X}_{2}\right)$, and customer satisfaction $\left(\mathrm{X}_{2}\right)$ on customer loyalty $(\mathrm{Y})$ at Bank Nagari main branch Padang. The results are shown in the following Table 2.

Table 2 Results of Second Sub Structure Analysis

\begin{tabular}{lcccc}
\hline \multicolumn{1}{c}{ Variable } & Coefficient & t-value & Sig. & Result \\
\hline Service Quality $(\mathrm{X} 1)$ & 0,233 & 2,470 & 0,015 & Significant \\
\hline Product Quality $(\mathrm{X} 2)$ & 0,212 & 2,298 & 0,024 & Significant \\
\hline Satisfaction $(\mathrm{X} 3)$ & 0,370 & 4,078 & 0,000 & Significant \\
\hline R Square $=0,442$ & & & &
\end{tabular}

From the above calculation results, the coefficient of each independent variable along with $t$ test results as follows:

a. The coefficient of Service Quality is 0.233 and t-value is 2,470 on sig. 0,015 which is smaller than alpha 0,05 . this result shows there is effect of service quality to loyalty.

b. The coefficient of Product Quality is 0,212 and t-value is 2,298 on sig. 0,024 which is smaller than alpha 0,05 . this result shows there is effect of product quality to loyalty.

c. The coefficient of Satisfaction is 0,370 and t-value is 4,078 on sig. 0,000 which is smaller than alpha 0,05 . this result shows there is effect of satisfaction to loyalty.

The calculations show that there is an influence of service quality on loyalty, the influence of product quality on loyalty, and the influence of satisfaction on loyalty. Based on the above calculation, it can be shown the analysis diagram as follows:

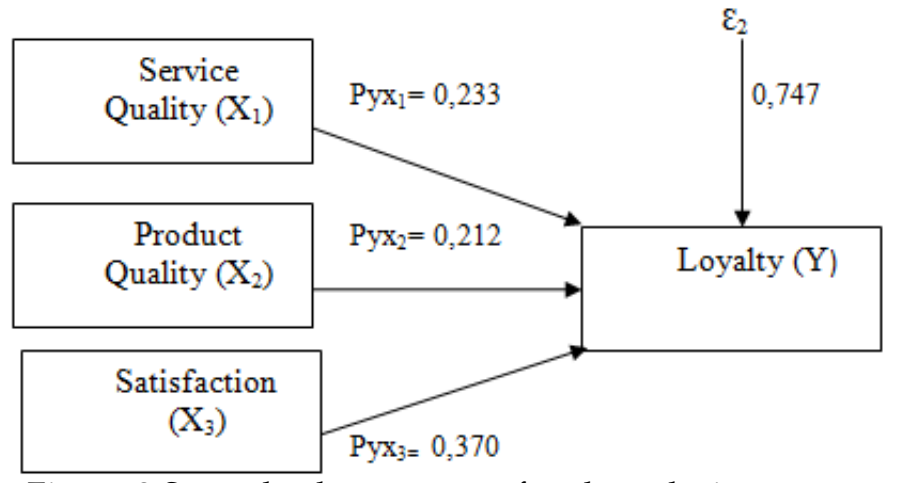

Figure 2 Second sub-structure of path analysis 
Based on the results of data analysis is known that service quality, product quality and satisfaction affect loyalty. Therefore, data analysis can be continued to the path diagram.

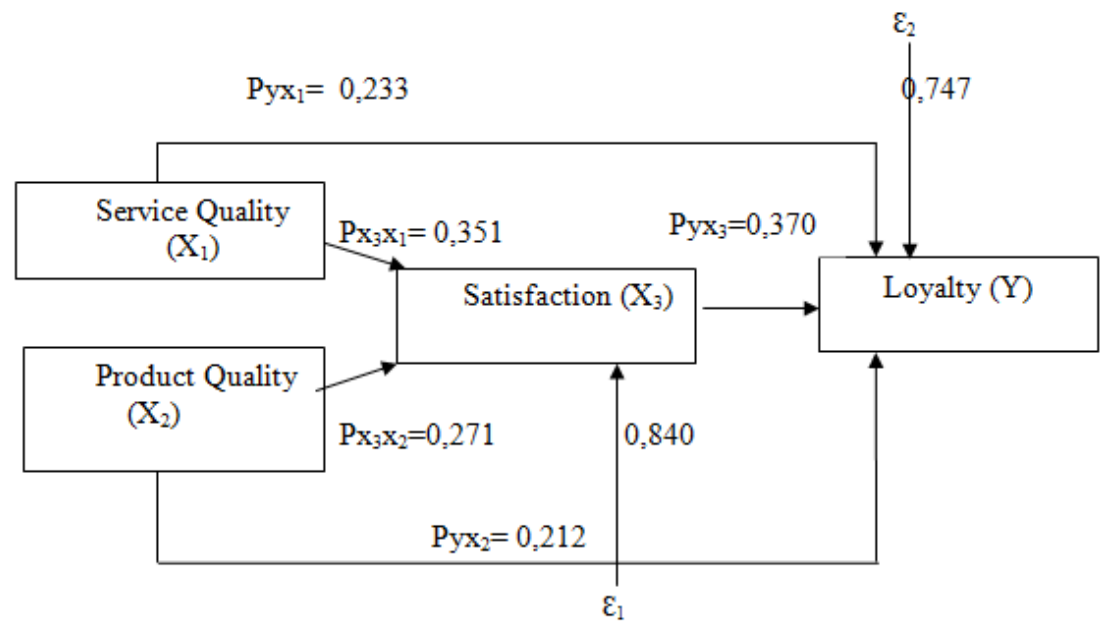

Figure 3 Final structure of path analysis

\section{The Effect of Service Quality on Satisfaction of Bank Nagari Customers of main branch Padang}

The results of t-test show value of path coefficient for service quality variable to customer satisfaction $(\mathrm{P} \times 3 \times 1)$ is 0.351 with $\mathrm{t}$-value for service quality variable 3.534 at significant value $0.001<$ 0.05 then $\mathrm{H}_{1}$ is supported accepted. Thus, there is significant influence between service quality to customer satisfaction of Bank Nagari branch of Padang.

The results of the first hypothesis test show that service quality significantly influence customer satisfaction of Bank Nagari main branch Padang. The higher quality of services provided to customers will certainly increase customer satisfaction. These findings prove that the higher quality of service consisting of reliability, responsiveness, assurance, intangibles, and empathy, will create high satisfaction in the customers of Bank Nagari main branch Padang.

Pursuant to result of path analysis known that influence of service quality to satisfaction (Px3x1) is 0.351 . This shows that the quality of service enough to play a role in determining whether or not satisfied customers of Bank Nagari Main branch Padang. This means that if the service is perceived by qualified customers will certainly make customers feel satisfied with Bank Nagari branch of Padang.

This is in line with the opinion Lovelock and Wirtz (2011) states the quality of service is a multidimensional construct consisting of five components, namely assurance, reliability, tangibility, empathy and responsiveness. The findings of this research are in line with research conducted by, Bloemer (1998), Ganguli (2011), Pattanayak (2017), Caruana (2002) which indicates that service quality positively affects satisfaction

\section{The Effect of Product Quality on Satisfaction of Bank Nagari Customers main branch Padang}

The results of t-test show value of path coefficient for product quality variable to customer satisfaction $(\mathrm{P} \times 3 \times 2)$ is 0.271 with $\mathrm{t}$-value for product quality variable 2.726 at significant value $0.008<$ 0.05 . So, $\mathrm{H}_{2}$ is supported, there is significant influence between product quality to customer satisfaction of Bank Nagari branch of Padang.

Based on the findings of this research can be said that the relationship of product quality with customer satisfaction cannot be separated from the superiority of Bank Nagari Padang. To realize a quality product that leads to customer satisfaction, the bank must be able to identify who its customers, so that will be able to understand the level of perception and expectations of service 
quality. Quality of service should be customer oriented, because the good judgment of poor quality of services provided by a business entity is determined by the perception of its users.

Based on the result of path analysis, it is known that the effect of product quality on customer satisfaction $(\mathrm{P} \times 3 \times 2)$ is 0,271 . This shows that product quality is enough to play a role in determining whether or not the customers of Bank Nagari branch Padang. This means that if the product used by qualified customers will certainly make customers feel satisfied with Bank Nagari branch Padang.

This is in line with the opinion of Cannon et al. (2008: 143), which suggests product quality is the ability of the product to satisfy the needs or desires of consumers. Churchill and Coral (1982) which express satisfaction is the result of use which is the ratio of the customer to the benefits and costs associated in obtaining the experience of any product or service with respect to the expected results. The findings of this study are in line with the research conducted by Murtiyanto (2011), Utami (2009), Pradita (2013), Ismail (2014), Aulia (2017) which indicates that product quality significantly affects satisfaction.

\section{The Effect of Service Quality on Customer Loyalty of Bank Nagari main branch Padang}

From result of $t$ test show value of path coefficient for service quality variable to customer loyalty (Pyx1) is 0.233 with $\mathrm{t}$-value for service quality variable 2.470 at significant value $0.015<0.05$. So $\mathrm{H}_{3}$ is supported, there is significant influence between service quality to the loyalty of customers of Bank Nagari Branch of Padang.

Based on the results of testing the third hypothesis is known that the quality of service significantly influences customer loyalty of Bank Nagari main branch Padang. The higher quality of services provided to customers will certainly increase customer loyalty of Bank Nagari main branch Padang. The findings of this study prove that the higher quality of service consisting of reliability, responsiveness, assurance, intangibles, and empathy will create high loyalty to customers of Bank Nagari main branch Padang

The results of this study are supported by the results of descriptive analysis is known that customer loyalty is in enough categories that influenced by the quality of service is also in the category enough. This proves that with good service has created high loyalty of customers, it certainly provides an opportunity to Bank Nagari to increase customer loyalty to be high by improving the quality of service to be high as well.

This is in line with the opinion of Delgado-Ballester (2001) that service quality is an effective tool for keeping customers loyal to the bank, once a loyal customer, they will generate positive words from the bank and will spend more and less likely will switch to another service provider. The findings of this study are in line with research conducted by Bei and Bei (2001), Bloemer at al (1998), Lewis (2006), Ganguli (2011), Makanyeza (2017), Caruana (2002) have a positive effect on customer loyalty.

\section{The Effect of Product Quality on Customer Loyalty of Bank Nagari Main Branch of Padang}

From result of $\mathrm{t}$ test show value of path coefficient for product quality variable to customer loyalty (Pyx2) is 0.212 with $\mathrm{t}$-value for product quality variable 2.298 at significant value $0.024<0.05$. Thus, $\mathrm{H}_{4}$ is supported, there is significant influence between product quality to the loyalty of customers of Bank Nagari branch Padang.

Based on the results of the fourth hypothesis testing is known that product quality significantly influences customer loyalty of Bank Nagari main branch Padang. The more qualified products that are given to customers will certainly increase customer loyalty of Bank Nagari main branch Padang. The findings of this study prove that the more qualified products consisting of intangibility, inseparability, heterogeneity / variability will create high loyalty to the customers of Bank Nagari main branch Padang. 
The results of this study are supported by the results of descriptive analysis is known that customer loyalty is in enough categories that influenced by the quality of products that are also in the category enough. This proves that with a good product has created a high enough loyalty of customers, it certainly provides an opportunity for Bank Nagari to increase customer loyalty to be high by improving product quality to be high as well.

This is in line with Oliver's (1999) opinion, that loyalty is a firmly held commitment to repurchase or rejuvenate a consistently favored product or service in the future. The findings of this study are in line with the research conducted by Murtiyanto (2011), Utami (2015), Ismail (2014) which shows the quality of the products have a significant effect on loyalty.

\section{The Effect of Customer Satisfaction on Customer Loyalty of Bank Nagari main branch Padang}

From result of $t$-test show value of path coefficient for customer satisfaction variable to customer loyalty (Pyx3) is 0.370 with $\mathrm{t}$-value for customer satisfaction variable 4.078 at significant value $0.000<$ 0.05. thus, $\mathrm{H}_{5}$ is supported, meaning there is significant influence between customer satisfaction to the loyalty of customers of Bank Nagari branch Padang.

Based on the results of the fifth hypothesis test, it is known that customer satisfaction has a significant effect on customer loyalty of Bank Nagari branch Padang. The higher the level of customer satisfaction will certainly encourage increased customer loyalty to Bank Nagari main branch Padang. Based on the findings of this research can be said that customer loyalty will be influenced though the level of customer satisfaction because satisfaction can be known by way of consumer perception about an experience (or a small part of the experience) with their expectations. Customers will be satisfied when their expectations are met.

The results of this study are supported by the results of descriptive analysis found that customer loyalty is in the category enough that is influenced by customer satisfaction that is also in the category enough. This proves that with high customer satisfaction creates customer loyalty is also high enough. This proves that if customer satisfaction can be increased to be higher, of course will increase customer loyalty become high also.

This is in line with the opinions expressed by Bowen (2001) found that increased customer satisfaction led to an increase in customer loyalty. A positive correlation between satisfaction and loyalty will cause the customer's desire to recommend to others. The findings of this study are consistent with the research conducted by Delgado-Bellester and Manuera-Aleman (2001), Bei (2001), Bloemer (1998), Vinita (2015), Makanyeza (2017), Pattanayak (2017) have a positive effect on customer loyalty.

\section{Conclusions}

This study aims to examine the impact of service quality, product quality and customer satisfaction on customer loyalty of Bank Nagari main branch Padang. Some conclusions of this study are as follows. First, service quality has a significant effect on customer satisfaction of Bank Nagari branch Padang. Second product quality has a significant effect on customer satisfaction of Bank Nagari branch Padang. Third, service quality significantly affects customer loyalty of Bank Nagari branch Padang. Fourth, product quality significantly influences customer loyalty of Bank Nagari branch Padang. Fifth, customer satisfaction has a significant effect on customer loyalty of Bank Nagari branch Padang.

Based on the above conclusions, some recommendations are offered to increase customers loyalty of Bank Nagari branch Padang. First, things that must be improved for service quality is to maintain politeness in dealing with customers in providing services and improving employees' ability to be able to answer various customers' questions. Second, product quality can be improved by holding a drawing contest with prizes at various areas rather than centralized in one location so that it increases customers' participation. Further, product quality in terms of account opening process can be 
simplified by providing simpler application forms and improvements in saving book and ATM card design to make them more attractive. Finally, things that must be addressed in improving customers satisfaction is to improve employees' professionalism in providing services to customers and ensuring all services from employees exceeding the customers' expectation.

\section{References}

Aulia, Meslikhatula, (2017). Pengaruh kualitas produk, kualitas pelayanan dan hargaterhadap kepuasan konsumen Amanda Brownies. Jurnal Ilmu dan Riset Manajemen, 6(5).

Bei, L. T., and Chiao, Y. C. (2001). An Integrated model for the effects of perceived product, perceived service quality, and perceived price fairness on customer satisfaction and loyalty. Journal of Customer Satisfaction, Dissatisfaction and Complaining Behavior, 14, 125-139.

Bloemer, Josee. (1998). Investigating drivers of bank loyalty: The complex relationship between image, service quality and satisfaction. Journal of Bank Marketing, 16(7), 276-286.

Bowen, J. T. and Chen, S. L. (2001). The relationship between customer loyalty and customer loyalty and customer satisfaction. International Journal of Contemporary Hospitality, 13(5), 213-217.

Cannon, Joseph P., Perreault Jr., William D., \& McCarthy, J. (2008). Pemasaran Dasar-Dasar: Pendekatan Manajerial Global. $16^{\text {th }}$ Ed. Angelica, Diana \& Cahyani, R. (Translators). Jakarta: Salemba Empat.

Caruana, A. (2002). Service loyalty: The effects of service quality and the mediating role of customer satisfaction. European journal of Marketing, 36(11/12), 1338-52.

Churchill, G. Jr and Carol, S. (1982). An Investigation into the determinants of customer satisfaction. Journal of Marketing Research, 19, 491-504.

Delgado-Ballester, E., \& Manuera-Aleman, J. L. (2001). Brand Trust in the context of customer loyalty. European Journal of Marketing, 35(11/12), 1238-1258.

Ganguli, Shirshendu, \& Sanjid Kumar Roy. (2011). Generic technology-based service quality dimensions in banking impac on customer satisfaction and loyalty. International Journal of Bank Marketing, 29(2), 168-189.

Giovanis, Apostolos N., Dimitris Zondiros, \& Petros Tomaras. (2014). The antecedents of customer loyalty for broadband services: The role of service quality, emotional satisfaction and corporate image. Procedia - Social and Behavioral Sciences, 148(25), 236-244.

Ismail, Riswandhi (2014), Pengaruh kualitas layanan, kualitas produk dan kepuasan nasabah sebagai prediktor dalam meningkatkan loyalitas nasabah PT BPRS Syarikat Madani Batam. Jurnal Organisasi dan Manajemen, 10(2), 179-196.

Kranias, Argyrios and Maria Bourlessa. (2013). Investigating the relationship between service quality and loyalty in Greek banking sector. Procedia Economics and Finance, 5, $453-458$.

Lewis, B., \& Soureli, M. (2006). The antecedents of customer loyalty in retail banking. Journal of Customer Behaviour, 5, 15-31.

Makanyeza, Charles, \& Lovemore Chikazhe. (2017). Mediators of the relationship between service quality and customer loyalty: Evidence from the banking sector in Zimbabwe. International Journal of Bank Marketing, 35(3).

Murtiyanto, Kurniawan, Fatchur Rochman, \& Christin Susilowati. (2014). Pengaruh Kualitas Produk dan Layanan terhadap Kepuasan danLoyalitas Konsumen Pada Pengembang PT Araya Bumi Megah Malang. Jurnal Aplikasi Manajemen, 12(1).

Oliver, R. L. (1999). Whence consumer loyalty. Journal of Marketing, 63 (Special issue), 33- 44.

Pattanayak, Durgesh, Maddulety KoilaKuntla, \& Plavini Punyatoya. (2017). Investigating the influence of TQM, service quality and market orientation on customer satisfaction and loyalty in the Indian banking sector. International Journal of Quality and Reliability Management, 34(3), 362-377.

Prandita, Luli, \& Sri StyoIriani. (2013). Pengaruh kualitas produk, kualitas layanan dan emosional terhadap kepuasan pelanggan SOGO department store. Jurnal Ilmu Manajemen, 1(2). 
Shi, Yondong. Catherine Prentice, Wei He (2014). Linking service quality, customer satisfaction and loyalty in casinos, does membership matter? International Journal of Hospitality Management, 40 (July), 81.

Utami, Novita Dian, \& Hening Widi Oetomo. (2015). Pengaruh kualitasproduk, pelayanan, harga dan lokasi terhadap loyalitas dengan kepuasan sebagai variabel intervening. Jurnal Ilmu dan Riset Manajemen, 4(5).

Vinita, Kaura, Ch. Durga, Prasad, \& Sourabh, Sharma. (2015). Service quality, service convenience, price, and fairness, customer loyalty, and the mediating role of customer satisfaction. International Journal of Bank Marketing, 33(4).

Wirtz, J., \& Lovelock, C. (2011). Services Marketing: People, Technology, Strategy. $7^{\text {th }}$ ed. Essex: Pearson Education Limited. 